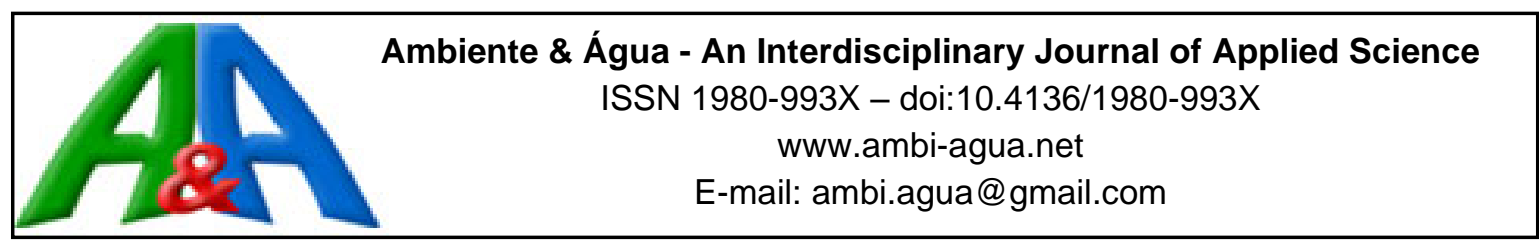

\title{
Analytic hierarchy process (AHP) applied to flood susceptibility in São José dos Campos, São Paulo, Brazil
}

\author{
ARTICLES doi:10.4136/ambi-agua.2574
}

Received: 04 Sep. 2020; Accepted: 17 Oct. 2020

\section{Lucas Guimarães da Silva ${ }^{\circledR}$; Celso de Souza Catelani Marcelo dos Santos Targa* (iD}

\author{
Programa de Pós-Graduação em Ciências Ambientais (PPGCA). Universidade de Taubaté (UNITAU), \\ Estrada Municipal Doutor José Luiz Cembranelli, n5000, CEP: 12081-010, Taubaté, SP, Brazil. \\ E-mail: eng.lucasguimaraes15@gmail.com, cscatelani@gmail.com \\ *Corresponding author. E-mail: targa.marcelo@gmail.com
}

\begin{abstract}
The changes in environmental factors in a hydrographic basin, mainly in the urban environment, enable different scenarios than the change of parameters in climatic, physical, political, and socioeconomic factors. Those changes may have immediate effects on indigenous populations, often making them vulnerable to the risk of flooding. This article evaluates the vulnerability to flooding in the municipality of São José dos Campos, State of São Paulo, Brazil using multicriteria analysis and geoprocessing techniques. Quantum GIS (QGIS) was used in the manipulation and processing of vector and matrix data related to the terrain slope, hydrography, geotechnics, and data history of flooding (2009 - 2018) in São José dos Campos. The hierarchy and criteria weighting processes were carried out, as well as the zoning of areas at risk of flooding. Thus, it was found that $23.81 \%$ and $2.17 \%$ of the municipal territory has high and very high susceptibility to flooding. It can be concluded that the combined use of multicriteria analysis and geoprocessing is an effective contribution to assist the management of public policies in order to obtain more assertive decisions in the prevention or reduction of flood risks.
\end{abstract}

Keywords: flooding, geoprocessing, multicriteria analysis.

\section{Processo de hierarquia analítica (AHP) aplicado à suscetibilidade a inundações em São José dos Campos, São Paulo, Brasil}

\section{RESUMO}

As mudanças de fatores ambientais em uma bacia hidrográfica, principalmente no meio urbano, possibilitam diferentes cenários a partir da alteração de parâmetros nos fatores climáticos, físicos, políticos e socioeconômicos. É possível que as alterações promovam efeitos imediatos para a sociedade, muitas vezes, tornando-a vulnerável ao risco de inundação. $\mathrm{O}$ objetivo desse trabalho é avaliar a vulnerabilidade à inundação no município de São José dos Campos, Estado de São Paulo, Brasil, utilizando análise multicritério e técnicas de geoprocessamento. Para tanto, utilizou-se o Quantum GIS (QGIS) na manipulação e processamento de dados vetoriais e matriciais relacionados à declividade, hidrografia, geotecnia e histórico de inundação (2009 - 2018) de São José dos Campos. Foram realizados os processos de hierarquização e ponderação de critérios, bem como o zoneamento de áreas de 
risco de inundação. Assim, constatou-se que 23,81\% e 2,17\% do território municipal apresenta suscetibilidade alta e muito alta à inundação. Pode-se concluir que a aplicação em conjunto da análise multicritério e do geoprocessamento é de efetiva contribuição para auxiliar a gestão de políticas públicas com fins de obter decisões mais assertivas na prevenção ou redução de riscos de inundação.

Palavras-chave: análise multicritério, geoprocessamento, inundação.

\section{INTRODUCTION}

The changes in environmental factors in a hydrographic basin, mainly in the urban environment, enable different scenarios of land use and occupation than the alteration of parameters in climatic, physical, political, and socioeconomic factors. These changes can have immediate effects on indigenous populations, often making them vulnerable to environmental risks. In the municipality of São José dos Campos, in the Metropolitan Region of Vale do Paraíba and the North Coast (RMVPLN), the urban area grew around several rivers and streams, adding to the population's inherent risk of flooding. In order to make informed decisions, these risks need to be analyzed by the public authorities based on a methodology that uses multicriteria. Among the methods developed in the Multicriteria Decisions Analysis environment, the most well-known is the Analytic Hierarchy Process (AHP) method developed by the mathematician Thomas Saaty in the 1960s.

The use of a multicriteria analysis method is recent in Brazil, and has been applied mainly to environmental problems which, due to the possibility of using specific criteria for each analysis, the application of the AHP method can be found in several studies, among them: geoenvironmental (Santos et al., 2007), risk of landslides (Faria et al. 2016; Meirelles et al., 2018), socio-environmental vulnerability (Marques et al., 2018) and susceptibility of soil to erosion (Santos et al., 2019).

Regarding flooding, analyzing the situation of springs that contribute to areas at risk of flooding, the municipality of São José dos Campos has a higher percentage of springs with preserved area compared to those occupied or recovered, up to a limit of 50 meters away (Coutinho et al., 2018). Socio-environmental vulnerability to flood events is found in stretches of less declivity and river plains. Also, most areas vulnerable to flooding have high population density and low socioeconomic standards (Marques et al., 2018).

The areas which are susceptible to periodic flooding are also associated with low-slope reliefs and with a predominance of Spodosols and Gleysols, which have reduced load capacity for the implementation of residential subdivisions (Santos et al., 2007).

The AHP method consists of structuring hierarchy levels of criteria, subcriteria, and alternatives for decision making (Saaty, 1990). This method involves absolute measures by comparison regarding a standard or relative measures by comparison in pairs (Saaty, 1987).

Based on the analysis of multicriteria methods applied to water-resource planning, the AHP method presented satisfactory results for decision making in different scenarios, as well as greater sensitivity to variation in relative weights (Zuffo et al., 2002).

In view of the above, future scenarios of occupations in areas at risk of flooding must be avoided and, therefore, it is necessary to make more assertive decisions in the search for better alternatives to reach the public interest. In this context, the objective was to evaluate the susceptibility to flood events through the mapping of areas in zones, using the AHP method and geoprocessing techniques for territorial and environmental planning in the municipality of São José dos Campos.

Rev. Ambient. Água vol. 7 (supplement) - Taubaté 2020 


\section{MATERIALS AND METHODS}

\subsection{Characterization of the study area}

The study was applied to the territory of the municipality of São José dos Campos, as seen in Figure 1, which has an area of 1,099.41 $\mathrm{km}^{2}$ and demographic density of 572.96 inhabitants $/ \mathrm{km}^{2}$ (IBGE, 2020). This area is part of the RMVPLN, a regional unit in the State of São Paulo, Brazil (São Paulo, 2012). The geographical coordinates of São José's ground zero are $23^{\circ} 10^{\prime} 47^{\prime \prime} \mathrm{S}$ and $45^{\circ} 53^{\prime} 14^{\prime \prime} \mathrm{W}$, the relief is characterized by morphological features of Serra da Mantiqueira, Médio Vale do Paraíba and Planalto do Paraitinga, while the altitude of the region varies from about 500 meters in the alluvial plain of the Paraíba do Sul River and from 2.082 meters in Pico do Selado, in the District of São Francisco Xavier, in the northern region of the municipality (São José dos Campos, 2020).

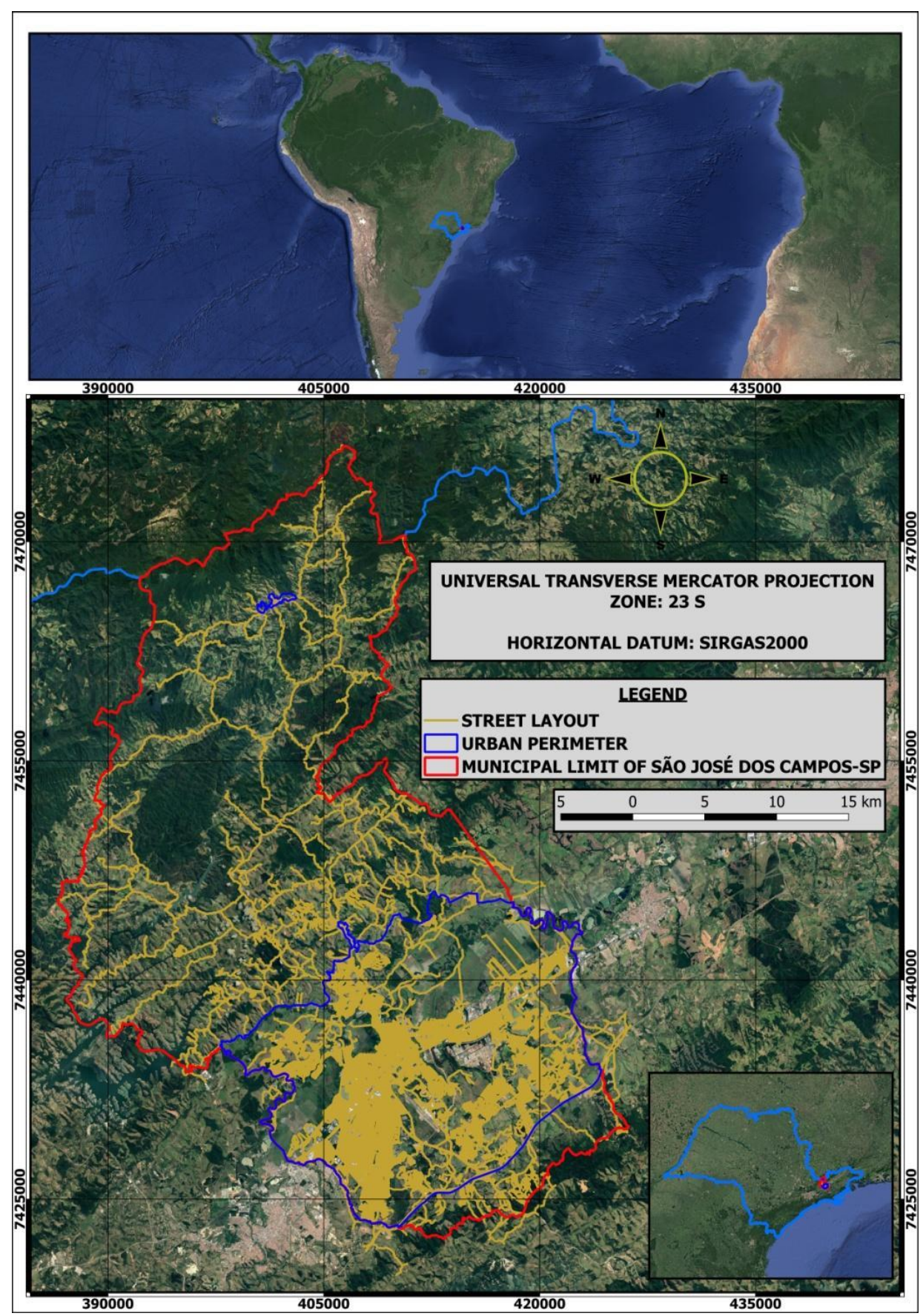

Figure 1. Location of the Municipality of São José dos Campos, SP. 
The soils in the municipality of São José dos Campos are the type Argisol, Cambisol, Gleysol, Oxisol, and Neosol (Oliveira et al., 1999). The urban hydrography covers the following watercourses: Cambuí, Cajuru, Lavapés, Senhorinha, and Vidoca streams and the Alambari, Buquira, Comprido, Jaguari, Pararangaba, Paraíba do Sul, and Peixe Rivers (São José dos Campos, 2017). As for the climate, the typical trend shows that the highest rainfall occurs in the summer while the lowest annual precipitation rates occur in the winter (Moura and Fisch, 2012).

\subsection{Applying of the Analytic Hierarchy Process (AHP) in flood areas}

In the preliminary phase of the application of the AHP method, subjective criteria of relative comparison were used based on the weighting of each sub-criterion. For this purpose, the Saaty (1990) judgment scale was observed to measure the intensity of the relationship between the pairs of criteria analyzed according to Table 1.

Table 1. Fundamental criteria judgment scale.

\begin{tabular}{ccc}
\hline Importance Values & Reciprocal Importance Values & Importance \\
\hline 1 & $\mathbf{1}$ & Equal importance \\
3 & $\mathbf{1 / 3}$ & Weak importance of one over another \\
5 & $\mathbf{1 / 5}$ & Essential or strong importance \\
7 & $\mathbf{1 / 7}$ & Very strong importance \\
9 & $\mathbf{1 / 9}$ & Absolute importance \\
$2,4,6,8$ & $\mathbf{1 / 2 , \mathbf { 1 / 4 }} \mathbf{1 / 6 , \mathbf { 1 }}$ & Intermediate values between adjacent \\
& & importance intensities \\
\hline
\end{tabular}

Source: Saaty (1990, adapted by the author, 2020).

In order to reduce uncertainties about the zoning of areas susceptible to flood risk, Equations 1, 2, and 3 were applied to obtain normalized values and, thus, check the consistency of these values, when the Consistency Ratio $(\mathrm{CR} \leq 0.1)$. However, these equations depend on the construction of the criteria judgment matrix from the combination of elements in pairs.

$$
\begin{aligned}
& \lambda_{\max }=\text { Average }\left[\frac{D \times W_{n}}{W_{n}}\right] \\
& C I=\frac{\lambda_{\max }-n}{n-1} \\
& C R=\frac{C I}{R I}
\end{aligned}
$$

Where:

$$
\begin{aligned}
& \mathrm{CR}=\text { Consistency ratio } \\
& \mathrm{RI}=\text { Random index } \\
& \mathrm{CI}=\text { Consistency index } \\
& \lambda_{\max }=\text { maximum eigenvalue } \\
& \mathrm{D}=\text { Sum of matrix row } \\
& \mathrm{W}_{\mathrm{n}}=\text { Eigenvector } \\
& \mathrm{n}=\text { Matrix dimension }
\end{aligned}
$$

\subsection{Zoning of criteria based on the application of geoprocessing techniques}

The cartographic base used in the study consists of vector and matrix products from the spatial database of the municipality of São José dos Campos (PSJC) and the mineral-resource 
research company (Companhia de Pesquisa de Recursos Minerais - CPRM), published in 2015.

The criteria analyzed are the proximity to rivers and streams $(30,50,100$, and $200 \mathrm{~m})$ of the watercourse domain zone (Zona de Domínio de Curso d'água - ZDCA), equivalent to the $30 \mathrm{~m}$ range, and soil types from the Geotechnical Map classification, both made available by the PSJC in vector format. One thousand six hundred ninety-seven flood records were made available by the Civil Defense of São José dos Campos (2009 - 2018) in printed format and terrain slope $(0-3 \%, 3-8 \%, 8-20 \%, 20-45 \%, 45-75 \%$, > 75\%) from CPRM's Digital Surface Model (MDS), from which parameters were distributed and combined in Quantum GIS (QGIS).

The normalization of matrix products was performed using the Fuzzy method and in a subjective hierarchical order, with a range of values from 0 to 1 . Thus, the closer to 1 , the greater the susceptibility of the criterion to flooding events.

Then, the rasterized maps of each selected criterion were produced from the conversion of vector data into standardized matrix data, with a spatial resolution of 30 meters, limiting the generation of the analysis product to the limit of the municipal territory.

However, the combined addition of matrix data for each criterion was processed to obtain the zoning of areas susceptible to flooding using the raster calculator tool, enabling the classification of levels of susceptibility to flooding events.

\section{RESULTS AND DISCUSSION}

\subsection{Flood zones criteria comparison matrix}

Based on Saaty's (1990) fundamental scale of importance, presented in Table 1, the matrix resulting from the comparison of criteria analyzed in pairs consists of the square matrix of order 4 (Table 2), of which the main diagonal represents the comparison between the same criteria. The elements arranged above and below the main diagonal represent the judgment of importance between different criteria.

Table 2. Comparison matrix of criteria.

\begin{tabular}{lcccc}
\hline & Terrain Slope & Distance to Rivers & Soils & Flood Records \\
\hline Terrain Slope & $\mathbf{1}$ & $1 / 5$ & $1 / 3$ & $1 / 9$ \\
Distance to Rivers & 5 & $\mathbf{1}$ & 3 & $1 / 3$ \\
Soils & 3 & $1 / 3$ & $\mathbf{1}$ & $1 / 5$ \\
Flood Records & 9 & 3 & 5 & $\mathbf{1}$ \\
\hline
\end{tabular}

The relative weights of each analyzed criterion were extracted from the quotient between the sum of $n$ elements of each criterion in the matrix and the total of the respective sums. The eigenvector $\left(\mathrm{W}_{\mathrm{n}}\right)$ defines the importance relationship between the criteria, with an interval from 0 to 1 , where the predominance between one criterion over the other is greater as $W_{n}$ is closer to 1 , as shown in Table 3.

Table 3. Priority and consistency values of the resulting matrix.

\begin{tabular}{lccccc}
\hline Criteria Analyzed & $\mathrm{W}_{\mathrm{n}}$ & $\mathrm{D} \mathrm{x} \mathrm{W}_{\mathrm{n}}$ & $\lambda_{\max }$ & $\mathrm{CI}$ & $\mathrm{CR}$ \\
\hline Flood Records & 0.537 & 2.490 & & & \\
Distance to rivers & 0.279 & 1.109 & & & \\
Soils & 0.135 & 0.483 & 4.114 & 0.038 & 0.042 \\
Terrain Slope & 0.049 & 0.209 & & & \\
\hline
\end{tabular}

Analyzing the matrix vectors, the flood records (Table 3) represent the highest degree of importance over the others, given the occurrence of flood episodes in the locations indicated on 
the map (Figure 2), based on the process of filtering the data history. Then, the distance to rivers presented a greater degree of importance based on the proximity to the areas of permanent preservation.

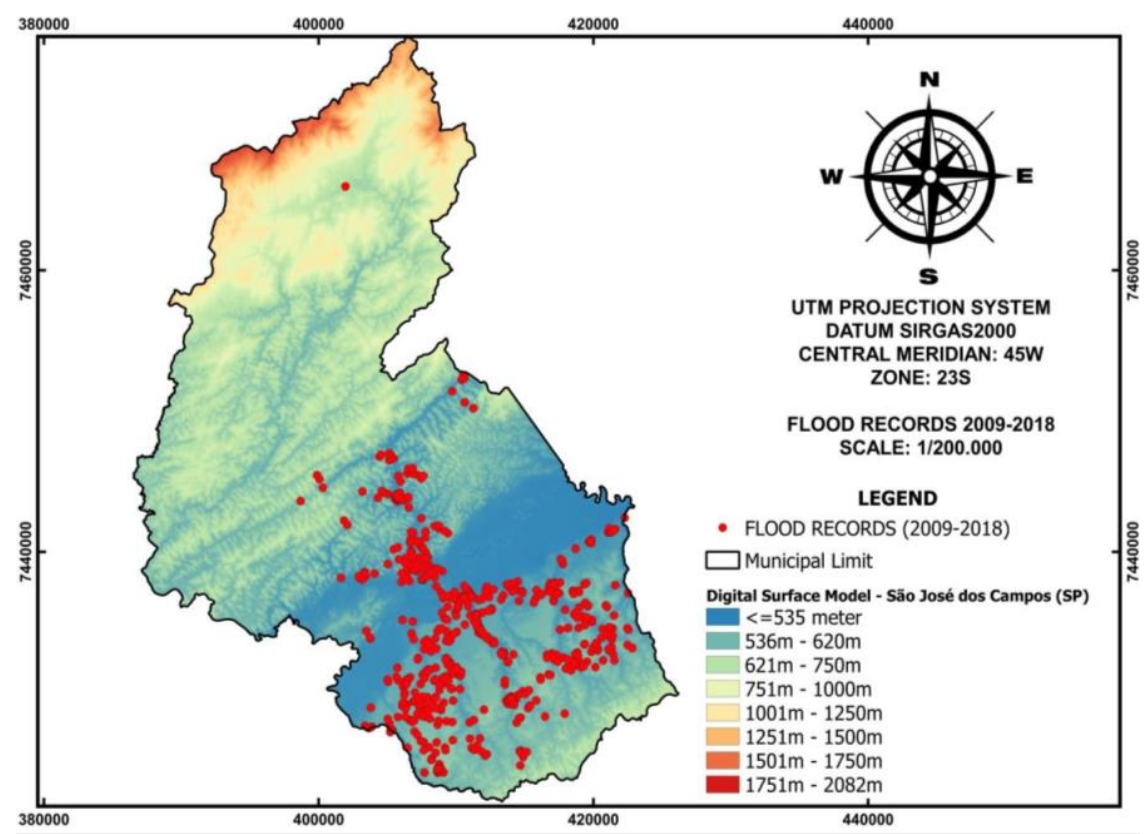

Figure 2. MDS classified with records of flood episodes that occurred in São José dos Campos, SP between the years 2009-2018.

On the other hand, the declivity characterized by intervals of inclination of the land surface and the types of soil in the study area presented the lowest degrees of importance, respectively, in relation to the analyzed criteria.

Knowing the dimension of the matrix (n), the tabulated value of 0.90 was adopted to express the Random Index, according to Saaty (1987).

The judgments of the analyzed criteria presented satisfactory statistical conditions, knowing that the calculation of the consistency ratio of the elements of the resulting matrix, obtained by Equation 3, reached a value lower than 0.1. In this way, the attributed relative values tend to avoid possible divergences in the zoning with susceptibility to flooding.

\subsection{Flood risk zoning by hierarchy and weighting}

In order to support territorial and environmental planning, the mapping of flood areas is essential in identifying critical points of potential occurrences of hydrological processes, seeking to avoid society's exposure to risk.

Thus, the digital image processing by a weighted combination of hierarchical data allowed estimating the susceptibility of the territory of São José dos Campos to flooding through the matrix data calculator available at QGIS and expressed in the form of Equation 4:

$$
\mathrm{SI}=0.537 \mathrm{RI}+0.279 \mathrm{DR}+0.135 \mathrm{SO}+0.049 \mathrm{DEC}
$$

Where:

$$
\begin{aligned}
& \text { SI = Susceptibility to flooding } \\
& \text { RI = Flood records } \\
& \text { DR = Distance to rivers } \\
& \text { SO = Soils } \\
& \text { DEC = Terrain slope }
\end{aligned}
$$


The areas of high and very high susceptibility to flooding represent $23.81 \%$ and $2.17 \%$ of the study area, respectively. Note that the areas that are classified with the highest degree of susceptibility are located in marginal strips of rivers and streams present in the urban environment, as observed in Figure 3, demonstrating the influence of the criterion of proximity to watercourses.

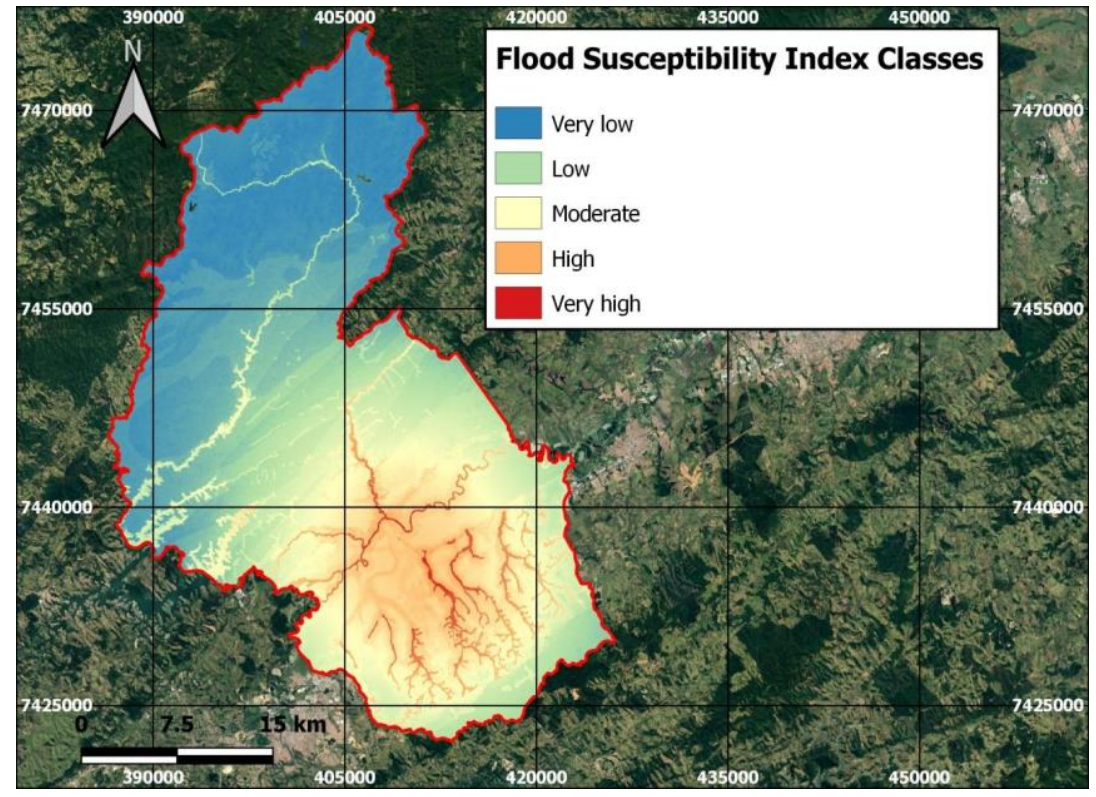

Figure 3. Flood susceptibility map of São José dos Campos, SP.

The environmental susceptibility to flooding is associated with the weighting of analyzed criteria. The areas that are close to the watercourses presented the lowest slope intervals and soils with low capacity to support the load weight due to probable saturation, such as Gleysols and Neosols (Oliveira et al., 1999) classified as group D, in the Soil Conservation Service (SCS) hydrological group (Sartori et al., 2005) that are characterized by low infiltration capacity. Therefore, the building of housing in these areas tends to present problems resulting from settlement and due to the reach of hydrological processes, so they are considered areas at risk of flooding.

\section{CONCLUSIONS}

This study produced the mapping of areas that are susceptible to flood risk with the joint application of geoprocessing techniques and multicriteria analysis AHP to assist the management of public policies in taking more assertive decisions in the prevention or reduction of flood risks. This mapping contains information that enables knowing the critical points of the territory, making it possible to reduce uncertainties related to the planning of public interest policies such as housing plans and programs.

The statistical verification of the applicability of the method used in the classification of criteria indicates the consistency of the methodology. Despite possible variations in the result of the consistency ratio value, within the acceptable limit, it is valid to admit the application of the decision-making methodology.

\section{REFERENCES}

COUTINHO, M. P. et al. Áreas de inundação no trecho paulista da bacia do Rio Paraíba do Sul e nascentes do Cadastro Ambiental Urbano. Revista Brasileira de Gestão Urbana, v. 10, n. 3, p. 614-623, 2018. https://doi.org/10.1590/2175-3369.010.003.ao09 
FARIA, D. G. M. et al. Aplicação do processo de análise hierárquica (AHP) no mapeamento de risco associado a escorregamentos no município de São José dos Campos-SP. Revista Brasileira de Cartografia, v. 68, n. 9, 2016.

IBGE. Estatísticas: cidades e estados. Rio de Janeiro, 2020.

MARQUES, M. L.; SILVA, M. C.; CAMARGO, D. M. Análise espacial da vulnerabilidade socioambiental no município de Campinas, SP, Brasil. Revista Brasileira de Cartografia, v. 69, n. 9, p. 1857-1870, 2018.

MEIRELLES, E. O.; DOURADO, F; COSTA, V. C. Análise multicritério para mapeamento da suscetibilidade a movimentos de massa na bacia do rio Paquequer-RJ. Geo UERJ, v. 33, 2018. https://doi.org/10.12957/geouerj.2018.26037

MOURA, Y. M.; FISCH, G. Método de análise para avaliação dos condicionantes climáticos, poluição atmosférica e saúde: estudo de caso para o município de São José dos Campos SP. Revista Biociências, v. 18, p. 35-43, 2012.

OLIVEIRA, J. B. et al. Mapa pedológico do Estado de São Paulo. Campinas: IAC/Embrapa, 1999. Mapa, escala 1:500.000.

SAATY, R. W. The analytic hierarchy process - What it is and how it is used. Mathematical Modelling, v. 9, n. 3-5, p. 161-176, 1987. https://doi.org/10.1016/0270-0255(87)904738

SAATY, T. L. How to make a decision: The analytic hierarchy process. European Journal of Operational Research, v. 48, n. 1, p. 9-26, 1990. https://doi.org/10.1016/03772217(90)90057-I

SANTOS, J. P. C.; PEREIRA CALDAS, V. I. S.; SILVA, A. S. Suscetibilidade a Erosão dos Solos da Bacia Hidrográfica Lagos - São João, no Estado do Rio de Janeiro - Brasil, a partir do Método AHP e Análise Multicritério. Revista Brasileira de Geografia Física, v. 12, n. 4, p. 1415-1430, 2019. https://doi.org/10.26848/rbgf.v12.4.p1415-1430

SANTOS, L. J. C. et al. Mapeamento da vulnerabilidade geoambiental do estado do Paraná. Revista Brasileira de Geociências, v. 37, n. 4, p. 812-820, 2007.

SÃO JOSÉ DOS CAMPOS. Secretaria de Urbanismo e Sustentabilidade. Plano Diretor de São José dos Campos: mapas temáticos (hidrografia). São José dos Campos, 2017.

SÃO JOSÉ DOS CAMPOS. Secretaria de Governança. São José em Dados: localização. São José dos Campos, 2020.

SÃO PAULO (Estado). Lei complementar $n^{\circ} 1.166$, de 09 de janeiro de 2012. Cria a região metropolitana do Vale do Paraíba e Litoral Norte, e dá providências correlatas. Diário Oficial [do] Estado, seção 1, v. 122, n. 6, 10 jan. 2012.

SARTORI, A.; GENOVEZ, A. M.; LOMBARDI NETO, F. Classificação Hidrológica de Solos Brasileiros para a Estimativa da Chuva Excedente com o Método do Serviço de Conservação do Solo dos Estados Unidos. Parte 1: Classificação. Revista Brasileira de Recursos Hídricos, v. 10, p. 19-29. 2005.

ZUFFO, A. C. et al. Aplicação de métodos multicriteriais ao planejamento de recursos hídricos. Revista Brasileira de Recursos Hídricos, v. 7, n. 1, p. 81-102, 2002. https://doi.org/10.21168/rbrh.v7n1.p81-102 